\title{
Livros Adquiridos
}

\section{Loyola}

MARGUERAT, D. (Org.). Novo Testamento: história, escritura e teologia. São Paulo: Loyola, 2015, 654p., ISBN 978-85-15-03627-1 (2 exemplares).

RÖMER, T.; MACCHI, J.-D.; NIHAN, C. (Orgs.). Antigo Testamento: história, escritura e teologia. São Paulo: Loyola, 2010, 847p., ISBN 978-8515-03700-1. 